УДК 633.356.4

DOI 10.36910/6775-2313-5352-2021-18-8

Дубчак Н. А., Кирик О. М.

Відокремлений підрозділ Національного університету біоресурсів і природокористування України «Бережанський агротехнічний інститут»

\title{
ОБГРУНТУВАННЯ РАЦІОНАЛЬНИХ КОНСТРУКТИВНО-КІНЕМАТИЧНИХ ПАРАМЕТРІВ РОБОЧИХ ОРГАНІВ АДАПТОВАНИХ КОРЕНЕЗБИРАЛЬНИХ МАШИН
}

Зрізування гички, викопування та очищення коренеплодів від домішок залежить не тільки від конструкиї та параметрів робочих органів коренезбиральної машини, але й від агробіологічних і фізико-механічних характеристик коренеплодів у період їх збирання. Вибір конструкції робочих органів $i$ налаштування параметрів $i$ режимів роботи модуля для зрізування гички, викопувальних $і$ очисних модулів самохідних коренезбиральних комбайнів регламентовані розмірними параметрами та формою коренеплодів $i$ фізико-механічним станом навколоплідного грунтового середовища. Отримані теоретичні математичні моделі (1) i (2) та емпіричні залежності (3)-(7) можуть бути використані для подальшої розробки та обтрунтування раціональних конструктивно-кінематичних параметрів робочих органів адаптованих коренезбиральних машин. Наведено результати експериментальних досліджень маси та товщини шару налиплого трунту на поверхні тіла викопаних коренеплодів залежно від їх розмірних характеристик і фізичного стану трунту. Встановлено, що маса налиплого грунту змінюється в межах від 10..220 г для кормових буряків, 35...290 г для иукрових буряків, до 90 г для столових буряків, до 65 г для моркви, $20 \ldots 360$ г для коренеплодів циккорію.

Ключові слова: кормові, иукрові, столові буряки; морква; коренеплоди ичикорію; маса налиплого грунту; товщина шару грунту; вологість грунту.

Постановка проблеми. Агробіологічні (розмірно-масові) та фізико-механічні властивості різних видів культур коренеплодів (кормових, цукрових, столових буряків, моркви, коренеплодів цикорію) під час їх збирання мають значний вплив на технологічний процес роботи машини та випадковий характер і коливаються в певних межах [1-5].

Проблеми аналізу та синтезу робочих органів для викопування та очищення коренеплодів від домішок, а особливо очищення коренеплодів від налиплого грунту на їх поверхнях, потребують передусім наявність наукової уяви про кількісні (масові) характеристики налиплого грунту на етапі викопування коренеплодів залежно від вологості та щільності грунту, розмірних характеристик коренеплодів і їх залягання в грунті [6-9], або в загальному від наявного стану навколоплідного грунтового середовища.

Розробка оптимальних типів і обгрунтування раціональних конструктивно-кінематичних параметрів робочих органів, структурної побудови та їх послідовності конструктивного розміщення у технологічно-компонувальних схемах базових модулів адаптованих самохідних коренезбиральних машин, повинно виконуватися на основі аналітичного та емпіричного моделювання вірогідних агробіологічних і фізико-механічних характеристик коренеплодів 3 врахуванням множини умов протікання технологічного процесу збирання різних культур $\mathrm{i}$ форм коренеплодів.

Огляд та аналіз попередніх досліджень. Аналіз останніх досліджень і публікацій показав, що в наукових працях недостатньо висвітлено питання, які характеризують результати експериментальних досліджень маси та товщини шару налиплого грунту на поверхні тіла коренеплодів у початковий момент їх викопування. У них наведено тільки загальні показники якості роботи коренезбиральних машин. Результати теоретичних досліджень даної наукової задачі наведено в працях, але перевірка адекватності розроблених моделей не проводилася.

Тому задачею дослідження є емпіричне обгрунтування функціональної зміни маси та товщини шару налиплого грунту на поверхні тіла викопаних коренеплодів від їх розмірних характеристик і фізичного стану грунту.

Виклад основного матеріалу. У результаті проведення теоретичних досліджень було одержано аналітичні залежності, які характеризують зміну прогнозування ймовірної маси $m_{\text {гp }}$ та товщини шару налиплого грунту $\delta_{z p}$ на поверхні тіла коренеплодів у початковий момент їх викопування від розмірних характеристик коренеплодів і фізичного стану грунту: 


$$
\begin{aligned}
& m_{\imath p}=\frac{\pi \rho_{z p}}{k_{W}}\left[\frac{4}{3}\left(\frac{2 L_{k}}{D_{k}}-1\right) \delta_{z p}^{3}+3 L_{k} k_{H_{1} L_{k}} \delta_{z p}^{2}+L_{k}^{2} k_{H_{1} L_{k}}^{2}\left(\frac{2 L_{k}}{D_{k}}-1\right)^{-1} \delta_{z p}\right]
\end{aligned}
$$

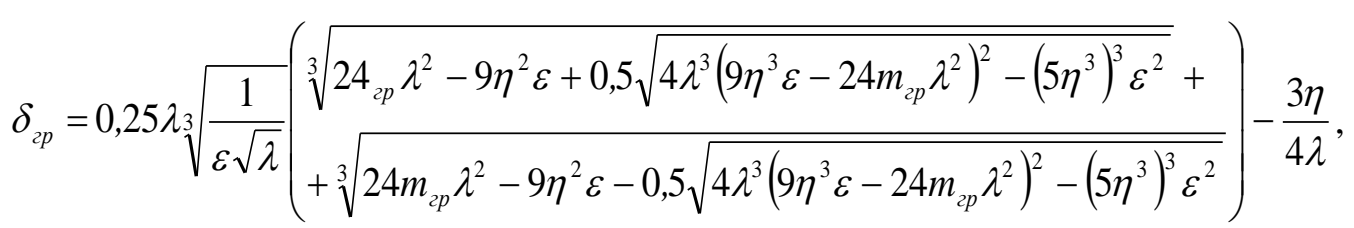

де $\rho_{2 p}-$ питома маса грунту, г $/ \mathrm{cm}^{3}$;

$L_{k}, D_{k}$ - довжина та діаметр головки коренеплоду, см;

$k_{H_{1} L_{k}}-$ коефіцієнт відношення глибини залягання коренеплоду в грунті до його довжини;

$k_{W}$ - коефіцієнт вологості грунту;

$\lambda=\left(2 L_{k} / D_{k}\right)-1$;

$\eta=L_{k} k_{H_{1} L_{k}}-$ глибина залягання коренеплоду в грунті, см;

$\varepsilon=\pi \rho_{c p} / k_{W}$.

Для підтвердження теоретичних закономірностей функціональної зміни маси та товщини шару налиплого грунту на поверхні тіла викопаних коренеплодів (1) i (2) провели польові експериментальні дослідження за зміни діапазону вологості грунту від $17 \%$ до $25 \%$. Для проведення дослідження було використано експериментальні установки (рис. 1).
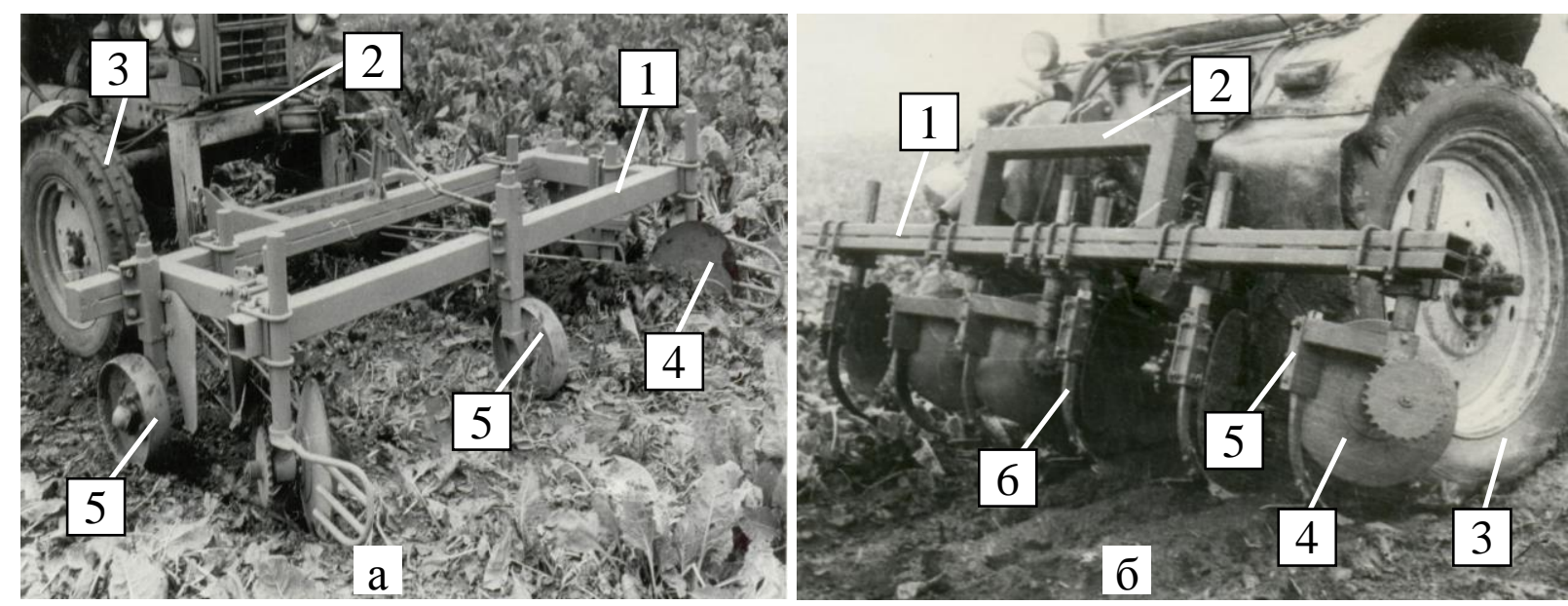

Рис 1. Загальний вигляд агрегату: a - для викопування коренеплодів цукрових, кормових i столових буряків; 1 - рама; 2 - сниця; 3 - трактор; 4 - сферичний диск; 5 - опорне регулювальне колесо; б - для викопування моркви та коренеплодів цикорію; 1 - рама; 2 сниця; 3 - трактор; 4 - сферичний диск; 5 - стояк; 6 - розрихлювач

Перед початком кожного експерименту брали визначали вологість грунту залікової ділянки поля на глибині ходу копача за стандартною методикою. Досліди проводили в різні добові строки та в відмінних кліматичних умовах на різних полях. Урожайність коренеплодів залікової ділянки, ширина якої становила 2,7 м (6 рядків коренеплодів 3 міжряддями 0,45 м), а довжина 15 м та висоту розташування коренеплодів відносно поверхні поля визначали за відомою методикою. Гичку, перед викопуванням коренеплодів, зрізували гичкозбиральною машиною. Після викопування коренеплодів пристроєм, який утворював їх валок, залишки гички на деяких коренеплодах дорізували вручну. Налиплий грунт з поверхні тіла викопаних коренеплодів очищували вручну (рис. 2), який зважували з похибкою $\pm 1,0$ г. При цьому після зчищення грунту з поверхні тіла кожного коренеплоду визначали його діаметр головки та 
загальну довжину коренеплоду з похибкою $\pm 0,1$ см.
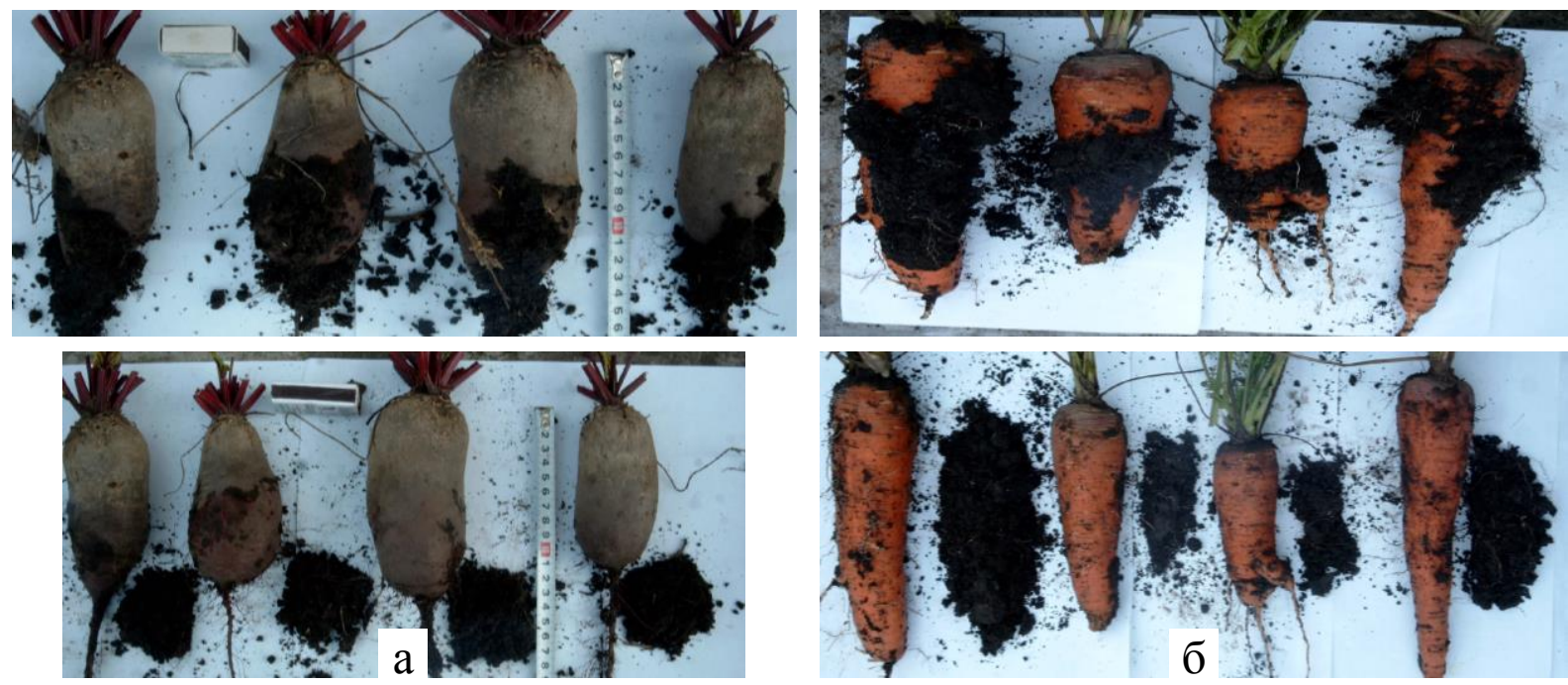

Рис. 2. Загальний вигляд коренеплодів: а - столових буряків; б - моркви

Характеристика факторів та рівні їх варіювання наведені в (табл. 1).

Таблиця 1

Характеристика та рівні варіювання фактора

\begin{tabular}{|c|c|}
\hline Найменування та позначення фактора & Рівні варіювання $(-1 ; 0 ;+1)$ \\
\hline \multirow{2}{*}{ Діаметр головки коренеплоду $D_{k}$, см } & Цукрові буряки: $8,0-12,0-16,0$ \\
& Кормові буряки: $14,0-20,0-26,0$ \\
& Столові буряки: $6,0-9,0-12,0$ \\
& Морква: $3,0-5,0-7,0$ \\
Коефіцієнт відношення $k_{H_{1} L_{k}}$ & Коренеплоди цикорію: $5,0-9,0-13,0$ \\
\hline \multirow{2}{*}{ Коефіцієнт вологості грунту $k_{W}$} & Цукрові буряки, морква: $0,8-0,9-1,0$ \\
& Кормові, столові буряки: \\
& $0,3-0,5-0,7$ \\
& Коренеплоди цикорію: $0,7-0,8-0,9$ \\
\hline & Цукрові, кормові, столові буряки, морква, \\
& коренеплоди цикорію: \\
& $0,7-0,98-1,26$ \\
\hline
\end{tabular}

Загальну довжину коренеплоду вимірювали до поперечного перерізу його хвостової частини діаметром 1,0 см. Глибину залягання коренеплоду в грунті визначали, як різницю загальної довжини та висоти розташування коренеплоду над поверхнею грунту. Вагу коренеплоду визначали 3 похибкою $\pm 0,1$ кг. Після визначення вологості грунту, з усього напрацьованого масиву даних, утворювали вибірку конкретного значення вологості грунту для коренеплодів різних розмірних характеристик.

Отримані числові дані кожного з експериментів заносили у стовбці відповідної таблиці факторного експерименту, при цьому обробку експериментального масиву даних провели 3 використанням прикладної програми для ПК Statistica 10.

Параметр оптимізації, тобто $m_{\imath p, i}$ та $\delta_{c p, i}$ знаходили у вигляді математичної моделі повного квадратного полінома.

Визначали коефіцієнт вологості грунту $k_{W}$, при цьому розбіжність отриманих експериментальних і прийнятих табличних значень вологості грунту не перевищувала $\pm 0,5 \%$, або розбіжність коефіцієнта вологості $k_{W}$ не перевищувала $\pm 0,03$.

Коефіцієнт $k_{H_{1} L_{k}}$ визначали числовим методом з похибкою $\pm 0,05$.

Після оцінки статистичної значущості коефіцієнтів рівняння регресії за критерієм Стюдента та перевірки адекватності емпіричного розподілу випадкових величин рівнянь регресії реальному експериментальному процесу за критерієм Фішера отримали рівняння 
регресії, які характеризують зміну маси $m_{i}$ та товщини шару $\delta_{i}$ налиплого грунту на поверхні тіла коренеплодів від $D_{k}$, коефіцієнтів $k_{H_{1} L_{k}}$ і $k_{W \gamma}$ у натуральних величинах:

- для коренеплодів кормових буряків

$$
\left\{\begin{array}{rl}
m_{K}= & 40,47+4,45 D_{k}+203,6 k_{H_{1} L_{k}}-176,5 k_{W}+5,5 D_{k} k_{H_{1} L_{k}}-6,43 D_{k} k_{W}- \\
& -120,5 k_{H_{1} L_{k}} k_{W}+2,82 D_{k}^{2}-0,08 k_{H_{1} L_{k}}^{2}+114,19 k_{W}^{2} ; \\
\delta_{K}= & 1,91-0,04 D_{k}-1,29 k_{H_{1} L_{k}}-2,25 k_{W}+0,003 D_{k} k_{H_{1} L_{k}}+0,004 D_{k} k_{W}+ \\
& +0,24 k_{H_{1} L_{k}} k_{W}+0,001 D_{k}^{2}+1,22 k_{H_{1} L_{k}}^{2}+0,94 k_{W}^{2}
\end{array} ;\right.
$$

- для коренеплодів цукрових буряків

$$
\left\{\begin{array}{rl}
m_{L}= & -137,76+27,74 D_{k}-29,55 k_{H_{1} L_{k}}+57,9 k_{W}+1,79 D_{k} k_{H_{1} L_{k}}-12,24 D_{k} k_{W}- \\
& -611,82 k_{H_{1} L_{k}} k_{W}-0,39 D_{k}^{2}+479,71 k_{H_{1} L_{k}}^{2}+222,35 k_{W}^{2} ; \\
\delta_{L}= & -1,69+0,024 D_{k}+3,2 k_{H_{1} L_{k}}+0,68 k_{W}-0,01 D_{k} k_{H_{1} L_{k}}-0,01 D_{k} k_{W}- \\
& -0,77 k_{H_{1} L_{k}} k_{W}-1,22 k_{H_{1} L_{k}}^{2}-0,05 k_{W}^{2}
\end{array} ;\right.
$$

- для коренеплодів столових буряків

$$
\left\{\begin{array}{rl}
m_{C}= & 122,54+1,2 D_{k}-184,13 k_{H_{1} L_{k}}-129,74 k_{W}+7,17 D_{k} k_{H_{1} L_{k}}-5,48 D_{k} k_{W}- \\
& -19,31 k_{H_{1} L_{k}} k_{W}+0,2 D_{k}^{2}+227,28 k_{H_{1} L_{k}}^{2}+62,24 k_{W}^{2} ; \\
\delta_{C}= & 0,16-0,1 D_{k}+0,02 k_{H_{1} L_{k}}-0,19 k_{W}+0,004 D_{k} k_{H_{1} L_{k}}-0,004 D_{k} k_{W}+ \\
& +012 k_{H_{1} L_{k}} k_{W}-0,17 k_{H_{1} L_{k}}^{2}+0,04 k_{W}^{2}
\end{array} ;\right.
$$

- для коренеплодів моркви

$$
\left\{\begin{array}{l}
m_{M}=35,84+17,21 D_{k}-73,02 k_{W}-18,75 D_{k} k_{W}+0,62 D_{k}^{2}+44,69 k_{W}^{2} \\
\delta_{M}=0,11+0,02 D_{k}-0,2 k_{W}-0,02 D_{k} k_{W}+0,09 k_{W}^{2}
\end{array} .\right.
$$

- для коренеплодів цикорію

$$
\left\{\begin{array}{l}
m_{K Ц}=15,63+12,42 D_{k}-38,12 k_{W}-9,75 D_{k} k_{W}+0,32 D_{k}^{2}+20,58 k_{W}^{2} \\
\delta_{K Ц}=0,06+0,012 D_{k}-0,09 k_{W}-0,008 D_{k} k_{W}+0,05 k_{W}^{2}
\end{array} .\right.
$$

Отримані емпіричні моделі (3)-(7) можуть бути застосовані для визначення маси $m_{i}$ та товщину шару $\delta_{i}$ налиплого грунту на поверхні тіла викопаних коренеплодів залежно від зміни діаметра коренеплоду $D_{k}$, коефіцієнта $k_{H_{1} L_{k}}$ та коефіцієнта вологості грунту $k_{W}$.

Аналіз емпіричних моделей, або рівнянь регресії (3)-(7) показує, що основними складовими величинами, які мають значний вплив на зміну маси $m_{i}$ налиплого грунту на поверхні тіла викопаних коренеплодів $€$ коефіцієнт $k_{H_{1} L_{k}}$, або коефіцієнт співвідношення глибини залягання коренеплоду в грунті до його загальної довжини та коефіцієнт вологості грунту $k_{W}$. Зміна діаметра коренеплоду $D_{k}$ має не суттєве значення на кінцевий результат.

Висновки. Отримані теоретичні математичні моделі (1) і (2) та емпіричні залежності (3)(7) можуть бути використані для подальшої розробки та обгрунтування раціональних конструктивно-кінематичних параметрів робочих органів адаптованих коренезбиральних 
машин.

\section{Інформаційні джерела}

1. Гурченко О. П., Барановський В. М. Результати випробування модернізованої коренезбиральної машини МКК-6А. Механізація та електрифікація сільського господарства. 1995. № 81. С. 57-60.

2. Барановський В. М., Соломка В. О., Онищенко В. Б. Вибір параметрів при конструюванні гвинтового конвеєра. Вісник ХДТУСГ. 2001. Т. 8(2). С. 209-215.

3. Барановський В. М. Конструктивно-технологічні принципи адаптизації транспортноочисного комбінованого робочого органа коренезбиральних машин. Сільськогосподарські машини. 2005. Вип. 13. С. 18-24.

4. Барановський, В. М. Конструктивно-технологічні принципи застосування адаптивного викопувального робочого органу коренезбиральних машин. Науковий вісник НАУ. 2005. № 73(1). C. 249-255.

5. Барановський В. М., Паньків М. Р., Дубчак Н. А. Очисна система вороху коренеплодів. Механізація сільськогосподарського виробництва. 2007. № 1(59). С. 33-36.

6. Барановський В. М., Дубчак Н. А., Онищенко В. Б., Паньків М. Р. Математичні моделі маси налиплого грунту на коренеплодах кормових буряків. Вісник Львівського національного аграрного університету: агроінженерні дослідження. 2008. № 12(2). С. 314-326.

7. Барановський В. М. Результати теоретично-експериментальних досліджень секундної подачі вороху коренеплодів. Механізація сільськогосподарського виробництва. 2008. № 1. С. 111-120.

8. Барановський В. М., Рамш В. Ю.Оптимізаційні математичні моделі процесу викопування вороху коренеплодів пасивним сферичним диском. Вісник Львівського національного аграрного університету: агроінженерні дослідження. 2008. № 12(2). С. 337-349.

9. Барановський В. М., Герасимчук Г. А. Критерії оцінки технологічної ефективності процесу викопування коренеплодів. Вісник Львівського. національного аграрного університету: агроінженерні дослідження. 2009. № 14. С. 163-168.

10. Рамш В. Ю., Барановський В. М., Паньків М. Р., Герасимчук Г. А. Аналіз тенденцій розвитку робочих органів для сепарації вороху коренеплодів. Наукові нотатки. 2011. Вип. 31. C. $298-305$.

\section{Dubchak N.A., Kyryk O.M.}

Separated Subdivision of National University of Life and Environmental Sciences of Ukraine Berezhany Agrotechnical institute

\section{JUSTIFICATION OF RATIONAL CONSTRUCTIVE-KINEMATIC PARAMETERS OF WORKING BODIES OF ADAPTED ROOT COLLECTING MACHINES}

Pruning, digging and cleaning of roots from impurities depends not only on the design and parameters of the working bodies of the root harvesting machine, but also on the agrobiological and physico-mechanical characteristics of roots during harvesting. The choice of design of working bodies and adjustment of parameters and modes of operation of the module for cutting of a hyphen, digging and clearing modules of self-propelled root harvesters are regulated by dimensional parameters and the form of root crops and physical and mechanical condition of amniotic soil environment. The obtained theoretical mathematical models (1) and (2) and empirical dependences (3) - (7) can be used for further development and substantiation of rational constructive-kinematic parameters of working bodies of adapted root-harvesting machines. The results of experimental studies of the mass and thickness of the layer of sticky soil on the body surface of excavated roots depending on their dimensional characteristics and physical condition of the soil are presented. It is established that the mass of sticky soil varies from $10 \ldots 220 \mathrm{~g}$ for fodder beets, $35 \ldots 290 \mathrm{~g}$ for sugar beets, up to $90 \mathrm{~g}$ for table beets, up to $65 \mathrm{~g}$ for carrots, $20 \ldots 360 \mathrm{~g}$ for chicory roots. 
Дубчак Н. А., Кирик О. М.

Обособленное подразделение Национального университета биоресурсов и природопользования Украины «Бережанский агротехнический институт»

\section{ОБОСНОВАНИЕ РАЦИОНАЛЬНЫХ КОНСТРУКТИВНЫХ-КИНЕМАТИЧЕСКИХ ПАРАМЕТРОВ РАБОЧЕГО ОРГАНА АДАПТИРОВАННЫХ КОРЕНЕЗБИРАЛЬНИ МАШИНЫ}

Срезание ботвы, выкапывание и очистки корнеплодов от примесей зависит не только от конструкции и параметров рабочих органов коренезбиральнои машины, но $и$ от агробиологических и физико-механических характеристик корнеплодов в период их уборки. Выбор конструкции рабочих органов и настройки параметров и режимов работы модуля для срезания ботвы, викопувальних и очистных модулей самоходных коренезбиральних комбайнов регламентированы размерным параметрам и форме корнеплодов и физико-механическим состоянием околоплодного почвенной среды. Полученные теоретические математические модели (1) и (2) и эмпирические зависимости (3) - (7) могут быть использованы для дальнейшей разработки и обоснования рациональных конструктивно-кинематических параметров рабочих органов адаптированных коренезбиральних машин. Приведеньь результаты экспериментальных исследований массы и толщины слоя налипшего грунта на поверхности тела выкопанных корнеплодов в зависимости от их размерных характеристик $и$ физического состояния почвы. Установлено, что масса налипшего грунта изменяется в пределах от 10 ... 220 г для кормовой свеклы, 35 ... 290 г для сахарной свеклы, до 90 г для столовой свеклы, 65 г для моркови, 20 ... 360 г для корнеплодов циикория. 